\title{
Chapter 1 \\ Environmental Governance of the Baltic Sea: Identifying Key Challenges, Research Topics and Analytical Approaches
}

\author{
Michael Gilek, Mikael Karlsson, Sebastian Linke, and Katarzyna Smolarz
}

\begin{abstract}
The Baltic Sea ecosystem is subject to a wide array of societal pressures and associated environmental risks (e.g. eutrophication, oil discharges, chemical pollution, overfishing and invasive alien species). Despite several years of substantial efforts by state and non-state actors, it is still highly unlikely that the regionally agreed environmental objectives of reaching "good environmental status" by 2021 in the HELCOM BSAP (Baltic Sea Action Plan) and by 2020 in the EU Marine Strategy Framework Directive (MSFD) will be met. This chapter identifies key research topics, as well as presents analytical perspectives for analysing the gap between knowledge and action in Baltic Sea environmental governance. It does so by outlining important trends and key challenges associated with Baltic Sea environmental governance, as well as by summarising the scope and results of individual chapters of this interdisciplinary volume. The analysis reveals the development of increasingly complex governance arrangements and the ongoing implementation of the holistic Ecosystem Approach to Management, as two general trends that together contribute to three key challenges associated with (1) regional and cross-sectoral coordination and collaboration, (2) coping with complexity and uncertainty in science-policy interactions and (3) developing communication and knowledge sharing among stakeholder groups. Furthermore, to facilitate analysis of environmental governance opportunities and obstacles both within and across
\end{abstract}

M. Gilek $(\bowtie) \cdot$ M. Karlsson

School of Natural Sciences, Technology and Environmental Studies, Södertörn University, 14189 Huddinge, Sweden

e-mail: michael.gilek@sh.se; mikael.karlsson@2050.se

S. Linke

Department of Philosophy, Linguistics and Theory of Science, University of Gothenburg, Box 200, 40530 Göteborg, Sweden

e-mail: sebastian.linke@gu.se

K. Smolarz

Department of Marine Ecosystem Functioning, Institute of Oceanography, University of Gdańsk, Al. Marszałka Piłsudskiego 46, 81-378 Gdynia, Poland

e-mail: oceksm@univ.gda.pl 
specific environmental issues, this chapter reviews the scientific literature to pinpoint key research issues and questions linked to the identified governance challenges.

Keywords Marine governance $\bullet$ Ecosystem approach to management $\bullet$ Institutional fit $\bullet$ Stakeholder participation $\bullet$ Science-policy interactions

\subsection{Introduction}

Governing marine environments is a highly complex and challenging enterprise (Gilek et al. 2015). This applies particularly to the heavily polluted and exploited, semi-enclosed and fragile Baltic Sea, situated in a densely populated region characterised by societal and ecological changes. This book aims for a better understanding of the complex arrangements of Baltic Sea environmental governance and gives proposals on how they could be developed for more sustainable outcomes. The book combines interdisciplinary investigations of the key environmental issues and risks in the area with in-depth analyses of problems, opportunities and barriers linked to governance structures and processes.

The Baltic Sea ecosystem is subject to a wide array of societal pressures such as hazardous chemicals, nutrients, oil discharges and invasive species, as well as exploitation of physical and biological resources such as fish (Ducrotoy and Elliott 2008; HELCOM 2010). For example, municipal wastewater, agricultural leakage and other sources have loaded the sea with phosphorus and nitrogen, which, together with intensive fishing and changing climate, have contributed to ecosystem regime shifts in some subbasins (Österblom et al. 2010) and a reduced capacity to deliver ecosystem goods and services to the people living in the nine coastal states (HELCOM 2010). Although most of these human pressures originate from activities in the Baltic Sea region (Fig. 1.1), significant contamination sources and other drivers of human-induced environmental change in the Baltic Sea also emanate from activities elsewhere and at larger scales, e.g. through long-range atmospheric transport of hazardous chemicals, introduction of invasive species through, e.g. shipping and global increases of anthropogenic greenhouse gases (e.g. Reckermann et al. 2012).

The coupled socioecological system associated with the Baltic Sea is today characterised by a dense multilevel web of governance structures (e.g. regulatory frameworks) and processes (such as science-policy interactions), which are linked to various forms of stakeholder participation and communication arrangements (e.g. Joas et al. 2008; Kern 2011). However, despite these thick layers of public and private governance arrangements, the Baltic Sea is still affected by serious environmental problems and risks due to various governance shortcomings (cf. HELCOM 2010). Furthermore, it is highly unlikely that the regionally agreed environmental objectives of reaching "good environmental status" by 2021 in the HELCOM BSAP 


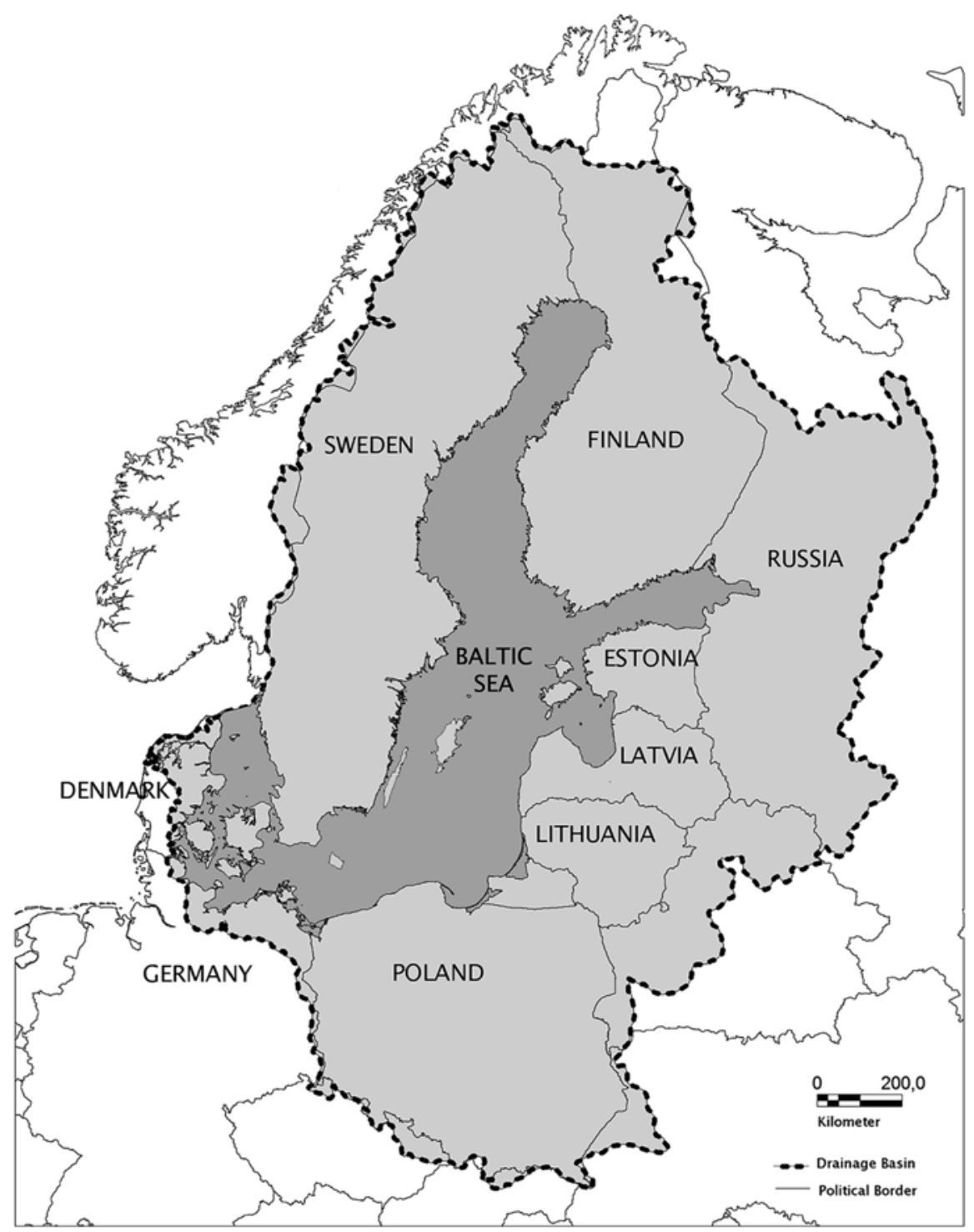

Fig. 1.1 The Baltic Sea region with its drainage basin and political borders (Modified from the GRID-Arendal Graphics Library, www.grida.no)

(Baltic Sea Action Plan) and by 2020 in the EU Marine Strategy Framework Directive (MSFD) will be met (Gilek and Kern 2011; Gilek et al. 2013; Kern 2011).

Consequently, this volume concentrates on the question of how key societal pressures and associated environmental risks (e.g. commercial fishing and the associated risks of overfishing, nutrient enrichment and eutrophication, shipping and oil discharges or invasive alien species) threatening the Baltic Sea environment are and 
could be governed. Our ultimate aim is to discuss pathways towards a more sustainable environmental governance of the Baltic Sea. Two general trends and associated challenges relating to environmental governance are of particular interest to the analysis.

First, linked to the complexity of human pressures and management responses in the Baltic Sea region, significant differences have evolved in the governance frameworks of various environmental issues, over time and between problem areas. The chapters of this book describe and analyse the evolution of this complex web of Baltic Sea environmental governance structures, through comparative investigations of in-depth case studies of five important problems and risks: eutrophication, overfishing, invasive alien species, chemical pollution and oil discharges.

Second, the Ecosystem Approach to Management (EAM) is today widely acclaimed in science and policy circles worldwide as a means to integrate measures in order to reach desired socioeconomic and environmental objectives, thereby facilitating sustainable development of marine and coastal areas (e.g. Backer et al. 2010; CBD 1998; Curtin and Prellezo 2010). According to this holistic approach, sustainable management of human activities and pressures should be based on the specific sensitivity and complexity of the ecosystem in focus, as well as on integration of cumulative pressures, e.g. over various sources of pollution and resource extraction (Hammer 2015; McLeod and Leslie 2009). Central to the concept is that management should be based on all forms of relevant knowledge and experience (e.g. scientific, local, actor-based knowledge), as well as on stakeholder participation, precaution and adaptability (cf. Hammer et al. 2011). However, since EAM is a very broad concept, views on what it exactly implies and how it should be implemented varies among and within different stakeholder groups, as well as among various groups of experts and researchers contributing to science-based advice. This multifaceted understanding and the framing and implementation of EAM is described and analysed in several chapters of the book with respect to the governance of particular environmental problems and risks, as well as in terms of challenges for processes of science-policy interactions, stakeholder communication and participation. In the concluding chapter, this discussion on problems and opportunities associated with achieving integration, across, for example, levels, sectors, interests and knowledge claims, is expanded to also include an attempt to identify broader pathways, as well as concrete institutional reforms and strategies that potentially could strengthen EAM implementation and outcomes.

Despite (and to some extent as a consequence of) these trends, i.e. the development of complex governance arrangements and the adoption of EAM, a number of key challenges remain as important obstacles for achieving sustainable governance of the Baltic Sea (Gilek et al. 2011), as well as marine ecosystems elsewhere (e.g. Gilek and Kern 2015). Of particular interest to the aims of this volume are three challenges that relate to multilevel, knowledge-based and inclusive environmental governance of the Baltic Sea. The first challenge concerns difficulties to establish adequate regional cross-sectoral collaboration among Baltic Sea policy actors due to existing institutional structures and procedures, power relations, cultures and varying policy styles in the different countries of the region. The second 
challenge concerns the uncertainties, ambiguities and complexities involved in perceiving, understanding and assessing different types of risks and problems, as well as how these risk perceptions and science-based assessments interact with environmental management. The third challenge concerns the difficulties in developing communication, exchange of value perspectives and knowledge sharing among key stakeholder groups based on participation, transparency and trust.

In this chapter we first introduce environmental governance and the key governance challenges identified and addressed in the book, as well as important research topics associated with these challenges. Second, we outline the general analytical and methodological approaches on which the research presented in this book is based. Finally, we summarise the book's structure and highlight key topics addressed in the individual chapters.

\subsection{Key Environmental Governance Challenges and Related Research Topics}

Over the last few decades, the term 'governance' and the specific topic of this book - 'environmental governance' - have become prevalent in the social and environmental science literature (e.g. Söderström et al. 2015a). The concept of governance, first established in public administration and taken up in political science, is used to depict a shift in responsibility from state to non-state actors (e.g. private or voluntary sectors) that affects structures and processes for collective action and decision-making (Stoker 1998). It emphasises social and political steering and acting in polycentric networks on different levels - local, regional, national, European and global (e.g. Delmas and Young 2009; Rosenau 2003; Wagner 2005). However, there is a great variation in how governance is defined and used. In other words, it refers more to a perspective than a coherent theory (e.g. Pierre and Peters 2000; Rhodes 1996). Our definition in this volume includes both structures - such as policy contexts, existing power relations among key actors, regulatory frameworks and organisational forms of decision-making, reflexivity and participation - and processes. Processes comprise aspects such as the evolution of organisations and interactions between, for instance, science and policy, as well as communication and interaction among policy-makers, scientists and other stakeholders. Processes also include the development of strategies, framings, communication and learning.

In many respects, EAM shares with environmental governance an interest in similar core topics, e.g. multilevel and multi-sector institutional interactions, knowledge integration and stakeholder arrangements and partnerships (Söderström et al. 2015a). In addition, it offers several additional focal areas and assumptions of value to the comprehensive analysis of environmental governance aimed for in this book. To begin with, there is a fundamental ecosystem-based focus in EAM that assumes that sustainable management of human activities and pressures can only be achieved if it is based on the sensitivity and complexity of the ecosystem in focus. In line with 
this, a central idea in EAM is that management needs to be based on congruence between institutions and ecosystems, as well as between institutions and environmental problems (institutional fit) (e.g. Folke et al. 2007). Furthermore, EAM aims to address environmental issues and their management in a holistic and integrated manner (e.g. McLeod and Leslie 2009), implying that the concept promotes an approach that analyses multiple objectives (e.g. socio-economic developments and environmental status), as well as multiple sectoral interests (e.g. fisheries, maritime transports, tourism, etc.). Finally, linked to discussions on the need for adaptive comanagement (e.g. Armitage et al. 2007), EAM offers approaches to analyse prerequisites and implications of adaptation, collaboration and learning linked to multilevel stakeholder arrangements and science-policy interfaces.

Research has also shown that the governance of environmental problems and risks ${ }^{1}$ in, for example, marine areas poses specific challenges and problems in that they (1) usually exhibit extremely complex multilevel interactions between riskcausing human activities and societal responses to these (Gilek and Kern 2015); (2) usually are associated with a striking scientific uncertainty (Udovyk and Gilek 2013); and (3) are characterised by social complexity which requires substantial, not seldomly contested, debate on what is at stake, what choices to make and which values are being assigned to different components of the ecosystem and to various strategies (Lidskog et al. 2009; van Asselt and Renn 2011). Hence, based on insights on governance in general and on EAM and environmental issues in particular (e.g. Lidskog et al. 2009), this book focuses on three key governance dimensions and challenges: multilevel and multi-sectoral governance structures, assessmentmanagement processes and interactions and stakeholder participation and communication, as discussed below.

\subsubsection{Multilevel and Multi-sectoral Governance Structures}

Environmental governance in general and marine governance in particular are characterised and challenged by complex multilevel and multi-sectoral interactions (cf. Gilek and Kern 2015; Lidskog et al. 2009). The Baltic Sea environmental governance system is, for example, made up of structures of national, international, European and transnational governance and can be perceived of as the outcome of continuous disparate processes over time, rather than being part of an intentionally designed governance arrangement (Andonova and Mitchell 2010). Furthermore, although marine environmental governance has traditionally focused on particular

\footnotetext{
${ }^{1}$ It can be argued that environmental issues, even if they already manifested themselves as negative environmental impacts, are associated with significant uncertainties about the type and extent of impacts, probabilities for future impacts, effectiveness of management responses, etc. Therefore, we argue in this volume that the risk governance concept, which acknowledges the central role of ignorance, uncertainty and ambiguity in decision-making on risks (Stirling 2007; Renn 2008) provides a suitable analytical perspective.
} 
sources of contamination (e.g. hazardous chemicals) and the use of natural resources (e.g. commercial fisheries), there are now strong policy ambitions to achieve multisector integration through approaches such as EAM, integrated ecosystem assessments (IEA) and marine spatial planning (MSP) (Douvere 2008; Karlsson et al. 2011; Linke et al. 2014; Udovyk and Gilek 2014; Walther and Möllmann 2014). Hence, understanding the processes and outcomes of Baltic Sea environmental governance requires that several multilevel and multi-sector interactions and associated challenges are simultaneously considered.

First, at the national level environmental governance may vary considerably among the states surrounding the Baltic Sea, which complicates international collaboration (e.g. Gilek et al. 2013). In the Baltic Sea region, we find countries such as Sweden that have gained a reputation as environmental pioneers since the 1970s and countries such as Poland and the three Baltic states that started to develop their environmental policy with a background of having been centrally planned economies.

Second, beyond the national level, Baltic Sea environmental governance is affected not only by global and EU agreements (such as the MARPOL Convention, EU regulations, directives and policies) but also by the regional international Helsinki Convention and its Baltic Sea Action Plan (BSAP) which came into effect from 2007 (HELCOM 2007). Even though this regionalisation of marine governance at the level of the entire Baltic Sea has the potential to improve multilevel coordination and cooperation by, for example, distinguishing between measures that can be implemented at international, EU and national levels, the successful harmonisation and coordination of actions still remain to be done (Gilek and Kern 2011). It is also possible that differences in, for example, path dependency, power relations and knowledge base will lead to differences in efficiency and outcomes of environmental governance at the regional level in various sectors (e.g. fisheries, shipping, agriculture, etc., cf. Linke et al. 2014).

Third, the Europeanisation of the Baltic Sea has developed quickly. This is most prominent in the area of fisheries as witnessed by the dominance of the EU Common Fisheries Policy (CFP) (Linke et al. 2014), but includes a proliferating body of EU legislation affecting various aspects of the marine environment under the guidance of EAM (cf. Raakjær and Tatenhove 2014). However, there is a division between EU policies that aim primarily at achieving good environmental status, such as the Marine Strategy Framework Directive (MSFD), and those aiming to regulate pollutants (e.g. the REACH chemicals regulation) and the use of natural resources, such as fish (e.g. EU CFP). This points to the need to achieve integration of various EU policies, since different policy objectives may lead to contradictions and conflicts between, for example, fisheries and marine nature conservation (De Santo 2015).

All these aspects are explored in this book. A particular focus is, however, placed on the macro-regional Baltic Sea level, because the most severe environmental issues in the Baltic Sea such as eutrophication and chemical pollution affect the Baltic ecosystem at large spatial scales that transgress national borders (HELCOM 2010). Moreover, national and local management measures are in practice often based on decisions at supranational levels. It has been argued that analyses of 
regional and macro-regional environmental governance (e.g. at the scale of the entire Baltic Sea) are less prevalent in the scientific literature on environmental governance than both at the local and global levels (e.g. Balsiger and Debarbieux 2011; Gilek and Kern 2015), which underlines the need for the regional perspective explored in this volume.

\subsubsection{Assessment: Management Processes and Interactions}

The interactions between the primarily science-based assessment sphere (i.e. generation of knowledge on environmental status, pressures, risks and problems) and the management sphere (i.e. decisions on and implementation of actions) have been described as key processes in environmental governance (Renn et al. 2011; Rice 2005). Science has since long been seen as the primary provider of knowledge and advice to guide environmental policy-making, especially in the case of managing environmental risks stemming from industrial technologies and pollutants (Karlsson et al. 2011). This has also been the case in the Baltic Sea region, both nationally and in relation to the activities of international organisations such as HELCOM and ICES (Udovyk and Gilek 2013).

However, interactions over science-policy interfaces (e.g. connected with the evaluation of what constitutes good environmental status and unacceptable levels of risk) are usually complicated by severe challenges connected with complexity, ignorance, uncertainty and ambiguity (Renn 2008; Stirling 2007), which frequently result in controversy in both society and science on appropriate risk assessment and management. It has been argued that scientific uncertainties and stakeholder disagreements and conflicts are particularly problematic for marine environmental governance when implementing holistic management approaches such as EAM and MSP (Linke et al. 2014; Rice 2005; Wilson 2009). Observations of impaired public trust in science and recognition of other legitimate knowledge providers, such as practitioners, stakeholders and experts based elsewhere than in traditional research organisations, have also been linked to cases of severe scientific uncertainty (Irwin and Michael 2003), in combination with a common politicisation of science (e.g. Eriksson et al. 2010; Weingart 1999). In response, Stirling $(2007)^{2}$ has argued that different types of environmental issues characterised by uncertainty and ambiguity require an expansion of traditional strategies in science and policy, to include precautionary and participative approaches.

As a consequence, the relationship between science and policy is changing on both a theoretical and practical level, particularly with regard to complex environmental issues such as marine governance. It is, however, despite a long and

\footnotetext{
${ }^{2}$ Stirling (2007) differentiates between four types of scientific incertitude: risk (quantitative data and knowledge exist), uncertainty (qualitative understanding of outcome, but not probabilities), ambiguity (poor knowledge about potential outcome) and ignorance; see Linke et al. (2016) for further explanation.
} 
strong tradition of scientific exploration of the Baltic Sea, still unclear if and how these changes will affect environmental governance issues in the Baltic Sea. Key questions in this context are with regard to if and how strategies for coping with the fundamental problems of different kinds of uncertainty have evolved for particular issues and sectors. This book will investigate these questions in-depth.

\subsubsection{Stakeholder Participation and Communication}

Various actors (e.g. policy-makers, social scientists, civil society organisations, etc.) generally agree that for societies to be able to manage and govern large-scale environmental risks, there is a need for transnational communication and multistakeholder participation, as well as for increased involvement of citizens through various processes of deliberation. For example, several scholars have argued for the need to facilitate stakeholder inclusion and deliberation in the governance of the marine environment and natural resources such as fish (cf. Jentoft and Chuenpagdee 2015; Mackinson et al. 2011). To facilitate stakeholder inclusion and participation, several new institutional arrangements have also been discussed, such as 'joint environmental policy-making' (Mol et al. 2000), 'multi-stakeholder dialogue' (Bendell 2000) and 'partnership' (Glasbergen et al. 2007). In the governance of regional seas such as the Baltic Sea, collaboration fostering initiatives by nongovernmental and subnational organisations (Kern and Löffelsend 2004), as well as transnational stakeholder networks, have also been found to be influential in many environmental governance contexts (Kern and Bulkeley 2009). Adding to this complexity, the institutions for Baltic Sea environmental governance have developed rather rapidly over the last few years in the form of venues for stakeholder participation such as the Regional Advisory Councils (RACs) in EU fisheries management (e.g. Linke et al. 2011) and stakeholder forums organised by HELCOM (e.g. Hassler et al. 2013). A core question is, however, to what extent these complex stakeholder arrangements open up collaboration and learning as opposed to impede possibilities to, for example, bridge sectoral interests.

Previous research on environmental governance has revealed several benefits of inclusive, communicative and participatory approaches (e.g. Lafferty and Meadowcroft 1996; Lovan et al. 2004), but also situations when participation may not be successful (e.g. Boström 2006). The advantages of more inclusive governance approaches relate to normative and instrumental reasons. Broad inclusion can be seen as normatively (intrinsically) 'good' because the idea of inclusiveness responds to democratic ideals around socially just representation. Citizens that are potentially affected by, for example, environmental pollution should be given access to data and processes and provided with opportunities to voice their concerns in communicative and even judicial forums, a principle established, for example, by the Aarhus convention (UN ECE 1998). The academic literature also discusses instrumental reasons for inclusiveness (e.g. Boström 2006; Jönsson et al. 2016). For example, it has been argued that inclusiveness generates new and more socially 
robust knowledge, stimulates mutual learning and ultimately facilitates capacity building in environmental governance.

Still, despite a basic descriptive understanding of the complex stakeholder arrangements and their recent developments in the Baltic Sea region (e.g. Hassler et al. 2013; Kern and Bulkeley 2009), there is a need for more in-depth critical analyses of framings, processes and outcomes linked to stakeholder participation in Baltic Sea environmental governance. Similarly, knowledge on environmental communication and framing is rather undeveloped in the Baltic Sea region, although some previous studies have addressed, for example, media framing (Jönsson 2011) and stakeholder participation in fisheries management (Linke et al. 2011). Clearly, stakeholders' perceptions, engagement and participation can all be influenced by how the Baltic Sea environment and its problems are communicated and framed in the public discourse (cf. Cox 2006). In particular, in line with this book's ambition to understand environmental governance structures and processes at the macroregional level of the Baltic Sea, there is a need to better understand the extent to which there are supranational communication arenas in the Baltic Sea region. These questions and perspectives relating to stakeholder participation and communication are all covered in the book and applied to experiences of environmental governance in the Baltic Sea region.

\subsection{Outline of Analytical and Methodological Approaches}

The empirical work presented in the chapters of this book was gathered as part of the interdisciplinary RISKGOV project ${ }^{3}$ which was based on a common analytical and methodological framework. Furthermore, empirical and analytical insights from the 'follow-up' COOP project ${ }^{4}$ were used to update and expand several case studies such as the one on eutrophication, as well as to develop cross-case comparisons and ideas for improvements.

The analytical framework aimed to ensure possibilities for cross-case comparisons by specifying focused governance dimensions in line with the arguments presented in Sect. 1.2 above, defining main research questions and providing the methodological requirements for interviews and document studies. These analytical and methodological specifications are outlined below. While reading this book, however, it is important to note that the authors of the individual chapters have been asked to focus on particularly important and interesting aspects in their respective cases. This means that the main aim of this volume is to explore challenging aspects

\footnotetext{
${ }^{3}$ RISKGOV (Environmental Risk Governance of the Baltic Sea) was funded by the BONUS+ programme and the Foundation for Baltic and East European Studies (2009-2015). www.sh.se/ riskgov.

${ }^{4} \mathrm{COOP}$ (Cooperating for Sustainable Regional Marine Governance) was funded by the Foundation for Baltic and East European Studies (2012-2015).
} 
associated with the different cases of environmental governance in the Baltic Sea, rather than to strive for full-fledged cross-case comparisons. ${ }^{5}$

To start with, five key environmental issues and risks from the Baltic Sea were identified for in-depth case studies: eutrophication, overfishing, invasive alien species, chemical pollution and oil discharges linked to marine transports. These issues have all been shown to be major, large-scale environmental problems in the Baltic Sea and are prioritised in national, regional (e.g. BSAP) as well as European (e.g. MSFD) marine regulatory frameworks (cf. Söderström et al. 2015b). Moreover, these cases represent a variety of types of environmental problems in terms of, for example, complexity of causes, scientific uncertainty and sociopolitical controversy (as will be described and analysed in the chapters of this volume).

The insights on governance in general and on environmental issues in particular described in Sect. 1.2 were the motivation behind choosing the three governance dimensions of primary design and analytic importance in the project: multilevel and multi-sectoral governance structures, assessment-management processes and interactions and stakeholder participation and communication (Fig. 1.2). Hence, the aim has been to study both the horizontal axis of risk governance focusing on a plurality of actors and norms and the vertical axis focusing on the connections and interactions between different scales in space and time (e.g. Lyall and Tait 2004). This means that although the main focus has been on the regional (i.e. transnational) Baltic Sea scale, interlinkages with other important levels such as nation states, the EU and global collaboration have been included to facilitate a comprehensive understanding of environmental governance of the Baltic Sea. In other words, the focus is on Baltic Sea regional environmental governance, but without losing sight of the relevance of other policy levels. Key research issues and governance challenges associated with the focused governance dimensions are further specified in Table 1.1.

Fig. 1.2 Outline of case studies of environmental governance and the key governance dimensions of Baltic Sea environmental governance analysed in this book

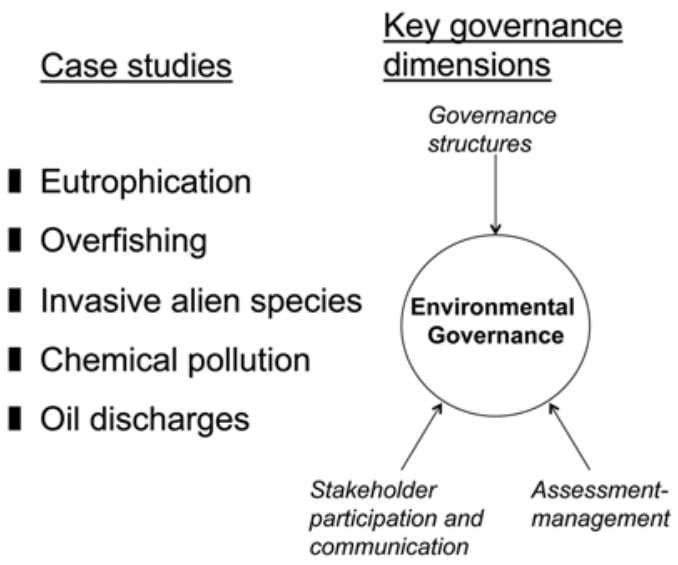

Key governance dimensions

Governance structures communication

${ }^{5}$ For other results from RISKGOV, please see project reports published on www.sh.se/riskgov. 
Table 1.1 Key research issues and environmental governance challenges linked to the studied dimensions of Baltic Sea environmental governance

\begin{tabular}{|c|c|c|}
\hline Governance dimensions & $\begin{array}{l}\text { Identified main governance } \\
\text { challenges }\end{array}$ & Key research issues \\
\hline \multirow{4}{*}{$\begin{array}{l}\text { Multi-level and } \\
\text { multi-sectoral } \\
\text { governance structures }\end{array}$} & \multirow{4}{*}{$\begin{array}{l}\text { Difficulties to establish } \\
\text { adequate regional cross-sectoral } \\
\text { collaboration }\end{array}$} & $\begin{array}{l}\text { Governmental organisations and } \\
\text { networks }\end{array}$ \\
\hline & & $\begin{array}{l}\text { Non-governmental organisations } \\
\text { and networks }\end{array}$ \\
\hline & & $\begin{array}{l}\text { Key policy documents and } \\
\text { regulatory frameworks }\end{array}$ \\
\hline & & $\begin{array}{l}\text { Multi-level and multi-sector } \\
\text { interactions }\end{array}$ \\
\hline \multirow[t]{2}{*}{$\begin{array}{l}\text { Assessment - } \\
\text { management processes } \\
\text { and interactions }\end{array}$} & \multirow{2}{*}{$\begin{array}{l}\text { Difficulties to cope with } \\
\text { uncertainties, ambiguities and } \\
\text { complexities in environmental } \\
\text { governance }\end{array}$} & $\begin{array}{l}\text { Organisation of science-policy } \\
\text { interactions; role of science- } \\
\text { based advice }\end{array}$ \\
\hline & & $\begin{array}{l}\text { Coping with uncertainty and } \\
\text { disagreements }\end{array}$ \\
\hline \multirow{2}{*}{$\begin{array}{l}\text { Stakeholder participation } \\
\text { and communication }\end{array}$} & \multirow{2}{*}{$\begin{array}{l}\text { Difficulties in developing } \\
\text { communication and knowledge } \\
\text { sharing among key stakeholder } \\
\text { groups }\end{array}$} & Problem and media framing \\
\hline & & $\begin{array}{l}\text { Arrangements for stakeholder/ } \\
\text { public involvement and } \\
\text { communication }\end{array}$ \\
\hline
\end{tabular}

In terms of empirical material, the five case studies of Baltic Sea environmental governance (Fig. 1.2) were based on a combination of several types of data sources acquired during 2009-2014: text analysis of key documents, interviews of key informants and roundtables. The case study work was organised in three consecutive steps guided by the analytical framework.

First, linked to each case study (cf. Fig. 1.2), a cross-disciplinary team of researchers (e.g. based in environmental science, ecotoxicology, environmental sociology, political science or media and communication studies) conducted a review of secondary material (existing empirical literature on each focused Baltic Sea environmental problem), as well as of primary sources such as documents and data bases on governance structures, problem assessment and stakeholder communication processes.

Second, each case study research team conducted interviews - approximately 15 per case - with key experts representing governmental and non-governmental organisations, comprising important parts of the governance structure of each issue area. The interviews were semi-structured (approx. 1-2 h) and developed in close collaboration with the different case study teams to facilitate comparability.

Third, to facilitate cross-case comparisons, three joint thematic round-table discussions (on regional governance structures, scientific knowledge and uncertainty and stakeholder participation and communication) were arranged in collaboration among all case study teams to get further input on similarities and differences among cases from experts, decision-makers and other stakeholders. 


\subsection{Structure and Content of the Book}

Following this introduction (Chap. 1), the book is divided into two parts. In the first part, five in-depth interdisciplinary case studies of environmental governance associated with large-scale environmental problems and risks in the Baltic Sea region (i.e. eutrophication, overfishing, invasive alien species, chemical pollution and oil discharges) are presented and analysed. In the second part of the book, key challenges and possible avenues for improvements are identified and analysed across the covered environmental issues, based on the three governance dimensions identified (Fig. 1.2; Table 1.1). Particular emphasis is placed on challenges for EAM implementation linked to multilevel and multi-sector environmental governance, science-policy interfaces, as well as stakeholder communication and participation.

The first part of the book starts with the case of eutrophication, one of the most serious environmental problems in the Baltic Sea. Karlsson and co-workers (Chap. 2) describe the complex problem and the governance structures and processes in place. The case shows how science-policy interactions have so far worked comparatively well, resulting in an ongoing implementation of EAM, although fundamental societal change is still needed in order to reach agreed objectives. In Chap. 3, Sellke and colleagues analyse the fisheries case, where scientific uncertainty, a multitude of actors representing contradictory interests and the tensions between top-down EU and bottom-up regional policies may paralyse decision-making. By pointing out the most pressing issues, the authors aim to provide input that may contribute to improving fisheries governance. In Chap. 4, Smolarz and co-workers take on the case of invasive alien species and describe the striking uncertainty on the one hand and the low interest among policy-makers and stakeholders on the other. In elaborating on a governance framework, including voluntary measures and improved coordination of public policies at various levels, the authors give attention to a severe problem that cannot continue to be neglected. Uncertainty is a striking component also in the following case of hazardous chemicals (Chap. 5). Karlsson and Gilek zoom in on the governance of three specific organohalogens that have caused severe problems and risks in the Baltic Sea. The authors compare measures taken over time by EU and HELCOM, respectively, and analyse what those experiences might mean for improving public governance in the future. Finally, Hassler (Chap. 6) identifies the primary drivers behind accidental oil spills and intentional oil discharges into the Baltic Sea. The author makes a case for global conventions and coordinated Port State Control in the former case and development of changed incentives for operators in the latter case, e.g. by institutionalising no-special-fee systems for waste management in ports.

The second part of the book is structured according to the three governance dimensions (governance structures, assessment-management processes and interactions and stakeholder participation and communication, see Fig. 1.2). Each chapter discusses and compares certain characteristics of the five specific cases presented in the first part of the book. In Chap. 7, Boström and colleagues describe the evolution of governance structures over time up to the present-day ambitions of implementing 
EAM and investigate if the present institutional and regulatory set-up supports EAM implementation. The authors apply the concept of reflexive governance in order to analyse various governance modes and elaborate on possible pathways to make Baltic Sea environmental governance more sustainable. Next, Linke and colleagues (Chap. 8) compare the science-policy interfaces linked to the five cases, with a focus on organisational structures and management of uncertainties and stakeholder disagreements. On that basis, possible routes for improving interaction between science-based advice and environmental management are discussed, in particular regarding implementation of the EAM. Finally, Jönsson and co-workers (Chap. 9) analyse how risks and problems are framed in the five cases and what role communication plays in the governance context with respect to institutions and procedures. The results point to the importance of widening the stakeholder concept and acknowledging the importance of citizen and public communication in practice.

Following the first and second part of the book, Gilek and Karlsson (Chap. 10) draw from the conclusions and recommendations of previous chapters to identify root problems and possible pathways for improving environmental governance in the Baltic Sea.

Acknowledgements The research leading to these results was funded by the Foundation for Baltic and East European Studies and the European Community's Seventh Framework Programme (2007-2013) under grant agreement $n^{\circ} 217246$ made with the joint Baltic Sea research and development programme BONUS, as well as by the German Federal Ministry of Education and Research (BMBF), the Swedish Environmental Protection Agency, the Swedish Research Council FORMAS, the Polish Ministry of Science and Higher Education and the Academy of Finland. We wish to thank these institutions for enabling this research. Two peer reviewers are also thanked for valuable comments on an earlier version of the chapter.

Open Access This chapter is distributed under the terms of the Creative Commons AttributionNoncommercial 2.5 License (http://creativecommons.org/licenses/by-nc/2.5/) which permits any noncommercial use, distribution, and reproduction in any medium, provided the original author(s) and source are credited.

The images or other third party material in this chapter are included in the work's Creative Commons license, unless indicated otherwise in the credit line; if such material is not included in the work's Creative Commons license and the respective action is not permitted by statutory regulation, users will need to obtain permission from the license holder to duplicate, adapt or reproduce the material.

\section{References}

Andonova LB, Mitchell RB (2010) The rescaling of global environmental politics. Ann Rev Environ Resour 35:255-282

Armitage DR, Berkes F, Doubleday N (eds) (2007) Adaptive co-management: collaboration, learning, and multi-level governance. UBC Press, Vancouver

Backer H, Leppänen JM, Brusendorff AC, Forsius K, Stankiewicz M, Mehtonen J, Pyhälä M, Laamanen M, Paulomäki H, Vlasov N, Haaranen T (2010) HELCOM Baltic Sea action plan - a regional programme of measures for the marine environment based on the ecosystem approach. Mar Pollut Bull 60:642-649 
Balsiger J, Debarbieux B (2011) Major challenges in regional environmental governance research and practice. Procedia Soc Behav Sci 14:1-8

Bendell J (ed) (2000) Terms for endearment: business, NGOs and sustainable development. Greanleaf Publishing, Sheffield

Boström M (2006) Regulatory credibility and authority through inclusiveness. Standardization organizations in cases of eco-labelling. Organization 13(3):345-367

CBD (Convention on Biodiversity) (1998) Report of the workshop on the ecosystem approach. Lilongwe. 26-28 Jan 1998. UNEP/COP/4/Inf.9

Cox R (2006) Environmental communication and the public sphere. SAGE Publications Ltd, London

Curtin R, Prellezo R (2010) Understanding marine ecosystem based management: a literature review. Mar Policy 34:821-830

De Santo E (2015) The marine strategy framework directive as a catalyst for maritime spatial planning: internal dimensions and institutional tensions. In: Gilek M, Kern K (eds) Governing Europe's marine environment. Europeanization of regional seas or regionalization of EU policies? Ashgate Publishing, Farnham

Delmas MA, Young OR (eds) (2009) Governance for the environment. New perspectives. Cambridge University Press, Cambridge

Douvere F (2008) The importance of marine spatial planning in advancing ecosystem-based sea use management. Mar Policy 32(5):762-771

Ducrotoy JP, Elliott M (2008) The science and management of the North Sea and the Baltic Sea: natural history, present threats and future challenges. Mar Pollut Bull 57:8-21

Eriksson J, Karlsson M, Reuter M (2010) Technocracy, politicization, and non-involvement: politics of expertise in the European regulation of chemicals. Rev Policy Res 27:167-185

Folke C, Pritchard L, Berkes F, Colding J, Svedin U (2007) The problem of fit between ecosystems and institutions: ten years later. Ecol Soc 12(1):30, http://www.ecologyandsociety.org/vol12/ iss $1 /$ art30/

Gilek M, Kern K (2011) Regional issues: environment. In: Henningsen B, Etzold T (eds) Political state of the region report 2011. Baltic Development Forum, Copenhagen, pp 68-71

Gilek M, Kern K (eds) (2015) Governing Europe's marine environment. Europeanization of regional seas or regionalization of EU policies? Ashgate Publishing, Farnham

Gilek M, Hassler B, Jönsson AM, Karlsson M (eds) (2011) Coping with complexity in Baltic Sea risk governance. Ambio 40(2):109-110

Gilek M, Hassler B, Engkvist F, Kern K (2013) The HELCOM Baltic Sea action plan: challenges of implementing an innovative ecosystem approach. In: Henningsen B, Etzold T, Pohl AL (eds) Political state of the region report 2013 - trends and directions in the Baltic Sea region. Baltic Development Forum, Copenhagen, pp 58-61

Gilek M, Hassler B, Jentoft S (2015) Marine environmental governance in Europe: problems and opportunities. In: Gilek M, Kern K (eds) Governing Europe's marine environment. Europeanization of regional seas or regionalization of EU policies? Ashgate Publishing, Farnham

Glasbergen P, Biermann F, Mol APJ (eds) (2007) Partnerships, governance and sustainable development. Reflections on theory and practice. Edward Elgar, Cheltenham

Hammer M (2015) The ecosystem management approach. Implications for marine governance. In: Gilek M, Kern K (eds) Governing Europe's marine environment. Europeanization of regional seas or regionalization of EU policies? Ashgate Publishing, Farnham

Hammer M, Balfors B, Mörtberg U, Petersson M, Quin A (2011) Governance of water resources in the phase of change: a case study of the implementation of the EU Water Directive in Sweden. Ambio 40(2):210-220

Hassler B, Boström M, Grönholm S (2013) Towards an ecosystem approach to management in regional marine governance? The Baltic Sea context. J Environ Policy Plan 15(2):225-245

HELCOM (2007) HELCOM Baltic Sea action plan. Available from: http://helcom.fi/Documents/ Baltic\%20sea\%20action\%20plan/BSAP_Final.pdf 
HELCOM (2010) Ecosystem health of the Baltic Sea 2003-2007: HELCOM initial holistic assessment. Baltic Sea Environmental Proceedings No. 122

Irwin A, Michael M (2003) Science, social theory and public knowledge. Open University Press, Maidenhead

Jentoft S, Chuenpagdee R (2015) The 'new' marine governance: assessing governability. In: Gilek M, Kern K (eds) Governing Europe's marine environment. Europeanization of regional seas or regionalization of EU policies? Ashgate Publishing, Farnham

Joas M, Jahn D, Kern K (eds) (2008) Governing a common sea. Environmental policies in the Baltic Sea region. Earthscan, London

Jönsson AM (2011) Framing environmental risks in the Baltic Sea - a news media analysis. Ambio 40:121-132

Jönsson AM, Boström M, Dreyer M, Söderström S (2016) Risk communication and the role of the public: towards inclusive environmental governance of the Baltic Sea? In: Gilek M (ed) Environmental governance of the Baltic Sea. Springer, Dordrecht

Karlsson M, Gilek M, Udovyk O (2011) Governance of complex socio-environmental risks: the case of hazardous chemicals in the Baltic Sea. Ambio 40(2):144-157

Kern K (2011) Governance for sustainable development in the Baltic Sea region. J Balt Stud 42(1):67-81

Kern K, Bulkely H (2009) Cities, Europeanization and multi-level governance: governing climate change through transnational municipal networks. J Common Mark Stud 47(1):309-332

Kern K, Löffelsend T (2004) Sustainable development in the Baltic Sea region. Governance beyond the nation state. Local Environ 9(5):451-467

Lafferty WM, Meadowcroft J (eds) (1996) Democracy and the environment: problems and prospects. Edward Elgar, Cheltenham

Lidskog R, Soneryd L, Uggla Y (2009) Transboundary risk governance. Earthscan, London

Linke S, Dreyer M, Sellke P (2011) The regional advisory councils. What is their potential to incorporate stakeholder knowledge into fisheries governance? Ambio 40(2):133-144

Linke S, Gilek M, Karlsson M, Udovyk O (2014) Unravelling science-policy interactions in environmental risk governance of the Baltic Sea: comparing fisheries and eutrophication. J Risk Res 17(4):505-523

Linke S, Gilek M, Karlsson M (2016) Science-policy interfaces in Baltic Sea environmental governance: towards regional cooperation and management of uncertainty? In: Gilek $\mathrm{M}$ et al (eds) Environmental governance of the Baltic Sea. Springer, Dordrecht

Lovan R, Murray M, Shaffer R (eds) (2004) Participatory governance: planning, conflict mediation and public decision-making in civil society. Ashgate, Aldershot

Lyall C, Tait J (2004) Shifting policy debates and the implications for governance. In: Lyall C, Tait J (eds) New modes of governance. Developing an integrated policy approach to science, technology, risk and the environment. Ashgate, Aldershot, pp 3-17

Mackinson S, Wilson DC, Galiay P, Deas B (2011) Engaging stakeholders in fisheries and marine research. Mar Policy 35:18-24

McLeod K, Leslie H (eds) (2009) Ecosystem-based management for the oceans. Island Press, Washington, DC

Mol APJ, Lauber V, Liefferink D (eds) (2000) The voluntary approach to environmental policy: joint environmental policy-making in Europe. Oxford University Press, Oxford

Österblom H, Gårdmark A, Bergström L, Müller-Karulis B, Folke C, Lindegren M, Casisni M, Olsson P, Diekmann R, Blenckner T, Humborg C, Möllmann C (2010) Making the ecosystem approach operational. Can regime shifts in ecological- and governance systems facilitate the transitions? Mar Policy 34:1290-1299

Pierre J, Peters BG (2000) Governance, politics and the state. Macmillan Press, Basingstove

Raakjær J, van Tatenhove J (2014) Marine governance of European seas: introduction. Mar Policy 50:323-324

Reckermann M, Brander K, MacKenzie BR, Omstedt A (eds) (2012) Climate impacts on the Baltic Sea: from science to policy. Springer, Berlin

Renn O (2008) Risk governance: coping with uncertainty in a complex world. Earthscan, London 
Renn O, Klinke A, van Asselt M (2011) Coping with complexity, uncertainty and ambiguity in risk governance: a synthesis. Ambio 40(2):231-246

Rhodes RAW (1996) The new governance: governing without government. Polit Stud 44:652-667

Rice JC (2005) Implementation of the ecosystem approach to fisheries management - asynchronous co-evolution at the interface between science and policy. Mar Ecol Prog Ser 300:265-270

Rosenau JN (2003) Distant proximities. Dynamics beyond globalization. Princeton University Press, Princeton

Söderström S, Kern K, Boström M, Gilek M (2015a) Environmental governance and ecosystem management: avenues for synergies between two approaches. Interdisc Environ Rev (2016)

Söderström S, Kern K, Hassler B (2015b) Marine governance in the Baltic Sea: current trends of Europeanization and regionalization. In: Gilek M, Kern K (eds) Governing Europe's marine environment. Europeanization of regional seas or regionalization of EU policies? Ashgate Publishing, Farnham

Stirling A (2007) Risk, precaution and science: towards a more constructive policy debate. EMBO Rep 8:309-315

Stoker G (1998) Governance as theory: five propositions. Int Soc Sci J50:17-28

Udovyk O, Gilek M (2013) Coping with uncertainties in science-based advice informing environmental management of the Baltic Sea. Environ Sci Policy 29:12-23

Udovyk O, Gilek M (2014) Participation and post-normal science in practice? Reality check for hazardous chemicals management in the European marine environment. Futures 63:15-25

UN ECE (1998) Convention on access to information, public participation in decision-making and access to justice in environmental matters. Aarhus, 25 June 1998

van Asselt M, Renn O (2011) Risk governance. J Risk Res 14(4):431-449

Wagner RE (2005) Self governance, polycentrism and federalism: recurring themes in Vincent Ostrom's scholarly oeuvre. J Econ Behav Organ 57(2):173-188

Walther Y, Möllmann C (2014) Bringing integrated ecosystem assessments to real life: a scientific framework for ICES. ICES J Mar Sci 71:1183-1186

Weingart P (1999) Scientific expertise and political accountability: paradoxes of science in politics. Sci Public Policy 26:151-161

Wilson DC (2009) The paradoxes of transparency: science and the ecosystem approach to fisheries management in Europe. Amsterdam University Press, Amsterdam 